\title{
PENGARUH PERBEDAAN UMUR PANEN TERHADAP KANDUNGAN LEMAK Nitzschia sp.
}

Oleh:

\author{
Baiq Tri Khairina Ilhami ${ }^{(1)}$, Lalu Japa ${ }^{(2)}$, Sri Puji Astuti ${ }^{(3)}$, dan Rina Kurnianingsih ${ }^{(4)}$ \\ (1, (3) dan (4)Program Studi Biologi FMIPA Unram, dan (2) Program Studi Pendidikan Biologi \\ FKIP Unram
}

\begin{abstract}
ABSTRAK
Mikroalga merupakan protista berklorofil yang memanfaatkan energi matahari dan $\mathrm{CO}_{2}$ dalam proses fotosintesis sehingga dalam biomassanya terkandung bahan-bahan seperti: lemak, protein, dan karbohidrat. Salah satu jenis mikroalga yang memiliki kandungan lemak adalah Nitzschia sp. Kelebihan mikroalga sebagai bahan baku biodiesel jika dibandingkan dengan jarak, biji bunga matahari, jagung, dan tumbuhan lainnya yaitu pertumbuhan mikroalga yang sangat cepat, tidak bersaing dengan produksi pangan, tidak membutuhkan lahan yang luas, dan ramah lingkungan. Oleh karena itu, perlu dilakukan penelitian untuk mengetahui kandungan lemak tertinggi pada Nitzschia sp. berdasarkan umur kultivasi. Dilakukan penelitian eksperimental kuantitatif menggunakan Rancangan Acak Lengkap (RAL) dengan 5 kali panen dan 3 kali ulangan, percobaan dilakukan di Laboratorium Pakan Alami Balai Budidaya Laut (BBL) Lombok, Sekotong pada bulan Agustus sampai September 2014. Kadar lemak ditentukan dengan Metode Soxhlet. Hasil penelitian menunjukkan umur pemanenan hari ke-13 memiliki kandungan lemak tertinggi dengan persentase sebesar 1,84\% sedangkan kandungan lemak terendah pada umur panen hari ke-11 dengan persentase sebesar 0,89\%. Tinggi rendahnya kandungan lemak Nitzschia sp. dipengaruhi oleh nutrien, kepadatan sel dan faktor lingkungan media kultur.
\end{abstract}

\begin{abstract}
Photosynthetic Protist, microalgae can trap sun light energy and $\mathrm{CO}_{2}$ for photosynthesis process, and they produce lipid, protein, and carbohydrate. One species of microalga that can produce lipid in high portion of their total dry wight is Nitzschia sp. The lipid can highly use as raw material for biodiesel production. The benefits of microalga as source of biodiesel are they grow faster, they do not compete with other food soruces production, they do not need wide area, and they are invironmental friendly. A quantitative experiment research of rendom complete design was done in the Laboratorium Pakan Alami Balai Budidaya Laut (BBL) Lombok, Sekotong during the months of August to September 2014. The research was conducted in five time harfesting of each in three repetation The lipid content was ditermined using Soxhlet method. The results showing that the highest lipid content $(1.84 \%)$ of Nitzschia sp. occurred at the day of thirteen of culturing, and the lowest lipid content $(0.89 \%)$ of Nitzschia sp. was in the day of eleven of culture.
\end{abstract}




\section{A. PENDAHULUAN}

Wilayah perairan laut Negera Republik Indonesia mencapai luas 3,1 juta kilometer persegi dengan panjang garis pantainya 80.791 kilometer (Wiryawan et al., 2005) dan dengan sinar matahari yang cukup sepanjang tahun menjadikan Indonesia kaya akan keanekaragaman hayati termasuk mikroalga. Mikroalga merupakan protista berklorofil yang memiliki ukuran renik, tetapi mempunyai kemampuan memanfaatkan energi matahari dan $\mathrm{CO}_{2}$ untuk keperluan fotosintesis dan menghasilkan berbagai bahan organik seperti: protein, karbohidrat, lemak dan asam nukleat.

Salah satu mikroalga yang jumlahnya melimpah di perairan karena kemampuannya bertahan walaupun dalam kondisi ekstrim dan memiliki kandungan lemak yaitu Nitzschia sp., salah satu anggota dari kelas Bacillariophyceae (Abida, 2010). Menurut Widianingsih et al. (2011) kandungan lemak total pada mikroalga jenis Nitzschia sp. sebesar 71,51 $\%$, dari total berat kering. Selain dijadikan sebagai pakan alami, Nitzschia sp. juga memiliki potensi besar untuk dijadikan bahan baku biodiesel yang sangat menjanjikan. Biodiesel merupakan bahan bakar yang berasal dari tumbuhan dan memiliki sifat seperti minyak diesel

Pemanfaatan mikroalga sebagai bahan baku biodiesel memiliki beberapa kelebihan jika dibandingkan dengan jarak, biji bunga matahari, jagung, dan tumbuhan lainnya yaitu pertumbuhan mikroalga yang sangat cepat, tidak bersaing dengan produksi pangan, tidak membutuhkan lahan yang luas, dan ramah lingkungan (Panggabean et al., 2010).

Salah satu faktor yang mempengaruhi total kandungan lemak pada mikroalga yaitu umur pemanenan. Umur pemanenan tersebut erat kaitannya dengan pertumbuhan mikroalga yang sangat singkat dan fase pertumbuhannya. Pentingnya umur panen pada saat mengkultur fitoplankton melatarbelakangi penelitian ini agar dapat diketahui umur panen yang tepat dengan kandungan lemak yang tinggi sehingga Nitzschia sp. dapat digunakan sebagai bahan baku alternatif pembuatan biodisel.

Berdasarkan latar belakang di atas maka dapat dirumuskan suatu permasalahan "Berapa persen (\%) kandungan lemak Nitzschia sp. pada umur panen yang berbeda?"

Adapun tujuan dari penelitian ini adalah untuk mengetahui pengaruh perbedaan umur panen terhadap kandungan lemak dari Nitzschia sp..

Adapun manfaat yang didapatkan pada penelitian ini adalah dapat dijadikan sebagai informasi awal dan tambahan 
informasi bagi penelitian selanjutnya dalam upaya pemanfaatan mikroalga Nitzschia sp. sebagai bahan baku pembuatan minyak biodiesel.

\section{B. METODE PENELITIAN}

Penelitian

kuantitatif

eksperimental Rancangan Acak Lengkap

(RAL) dengan 5 kali pemanenan dan 3 kali ulangan ini dilaksanakan pada bulan Agustus sampai September 2014 di Laboratorium Pakan Alami Balai Budidaya Perikanan Laut (BBL) Lombok, Sekotong Lombok Barat. Pengujian kadar lemak pada Nitzschia sp. dilakukan di Laboratorium Analitik Universitas Mataram. Penelitian ini menggunakan eksperimen untuk melihat pengaruh umur panen terhadap kandungan lemak pada Nitzschia sp.. Data dianalisis menggunakan SPSS 16 dengan analisis Varians ANOVA satu arah (Sudjana, 1996).

Pemanenan biomassa Nitzschia sp. dilakukan dengan modifikasi metode flokulan yaitu metode pengendapan dengan menggunakan bahan kimia $\mathrm{NaOH}$ dengan perbandingan 1:1 $\quad(500 \quad \mathrm{ml}$ mikroalga : 0,5 gr NaOH) (Amini, 2005). Pemanenan dilakukan selama 5 kali dengan selang waktu 1 hari $(1,2,3,4,5)$. Pemanenan Nitzschia sp. dimulai pada hari ke-5 dari awal kultivasi kemudian pengendapan dilakukan selama 24 jam, setelah itu dilakukan pemisahan biomassa dan cairan jernihnya. Selanjutnya biomassa yang didapat disentrifuge selama 15 menit dengan kecepatan $1000 \mathrm{rpm}$. Pelet yang diperoleh kemudian dipisahkan dari cairan di atasnya untuk selanjutnya diuji kandungan lemaknya.

\section{HASIL DAN PEMBAHASAN}

\section{Pertumbuhan Nitzschia sp.}

Pada saat budidaya fitoplankton, hal utama yang harus diperhatikan yaitu media kultur. Media kultur digunakan sebagai tempat untuk tumbuh dan memperbanyak diri. Bentuk media kultur yang digunakan pada saat budidaya fitoplankton berbentuk cair yang mengandung beberapa senyawa kimia sebagai sumber nutrien. Namun tidak semua nutrien yang tersedia secara langsung dapat diserap dan digunakan oleh sel. Adapun syarat-syarat yang diperlukan yaitu bentuk dan sifat bahan, konsentrasi bahan, enzim serta lingkungan yang menyertainya (Kimbal, 1991).

Nutrien tersebut terdiri dari dua unsur yaitu unsur makro (macro elements) maupun unsur mikro (micro elements). Unsur makro terdiri atas fosfor, sulfur, nitrogen, kalsium, kalium, dan magnesium sedangkan unsur mikro terdiri dari seng, mangan, boron, besi, tembaga, cobalt, dan molibdenum. Menurut Fogg (1987) dan Komarawidjaya (2010) terdapat dua unsur 
pokok yang harus tersedia dalam media kultur yaitu unsur $\mathrm{N}$ dalam bentuk nitrat dan unsur $\mathrm{P}$ dalam bentuk fosfor. Keduanya merupakan faktor pembatas bagi kehidupan fitoplankton. Ketika melakukan kultur, air laut steril di tambahkan dengan pupuk Na medium dan silikat. Komposisi media kultur pupuk $\mathrm{Na}$ medium dapat dilihat pada Tabel 1 . Komposisi dari $\mathrm{Na}$ medium yang digunakan pada saat mengkultur Nitzschia sp. terdiri dari komponen utama yaitu unsur $\mathrm{N}$ dan $\mathrm{P}$.

Tabel 1. Komposisi Media Kultur Pupuk Na Medium

\begin{tabular}{clr}
\hline No. & Komposisi & Porsi \\
\hline 1. & $\mathrm{NaNO}_{3}$ & $100,0 \mathrm{gr}$ \\
2. & $\mathrm{Na}_{2} \mathrm{EDTA}$ & $18,1 \mathrm{gr}$ \\
3. & $\mathrm{NaH}_{2} \mathrm{PO}_{4} \mathrm{H}_{2} \mathrm{O}$ & $14,0 \mathrm{gr}$ \\
4. & $\mathrm{Na}_{2} \mathrm{SiO}_{3} \cdot 9 \mathrm{H}_{2} \mathrm{O}$ & $5,0 \mathrm{gr}$ \\
5. & $\mathrm{NaHCO}_{3}$ & $12,6 \mathrm{gr}$ \\
6. & Clewat 32 & $100,0 \mathrm{gr}$ \\
7. & Aquades & $1000,0 \mathrm{ml}$ \\
8. & Vitamin mix & $10,0 \mathrm{ml}$ \\
\hline
\end{tabular}

Nitzschia sp. termasuk dalam golongan diatom sehingga pada saat kultur ditambahkan silikat yang berguna untuk pembentukan dinding sel dan cangkang. Pada diatom dinding sel merupakan salah satu pelindung terhadap kondisi lingkungan yang berbeda-beda. Namun silikat yang dibutuhkan hanya dalam jumlah sedikit karena digunakan sebagai pembentukan rangka luar dan klorofil a (Chiu-Liao et al., 1983).

Nutrien merupakan salah satu penunjang kehidupan Nitzschia sp. sehingga dapat tumbuh dan memperbanyak diri sesuai dengan fasefase pertumbuhannya. Pada saat kultivasi, Nitzschia sp. menunjukkan pertumbuhannya sampai mencapai fase eksponensial. Artinya, terjadi pertambahan populasi dari hari ke hari kultur. Namun fase stasioner dan kematian tidak terlihat, karena pemeliharaan kultur terbatas sampai umur 13 hari pada hari terakhir kultur. Kultur (umur 13 hari) masih terlihat fase eksponensial.

\section{Hubungan Umur Panen Terhadap Kepadatan Sel}


Umur panen memiliki hubungan yang erat dengan kepadatan sel Nitzschia sp.. Hubungan tersebut dapat dilihat pada Gambar 1.

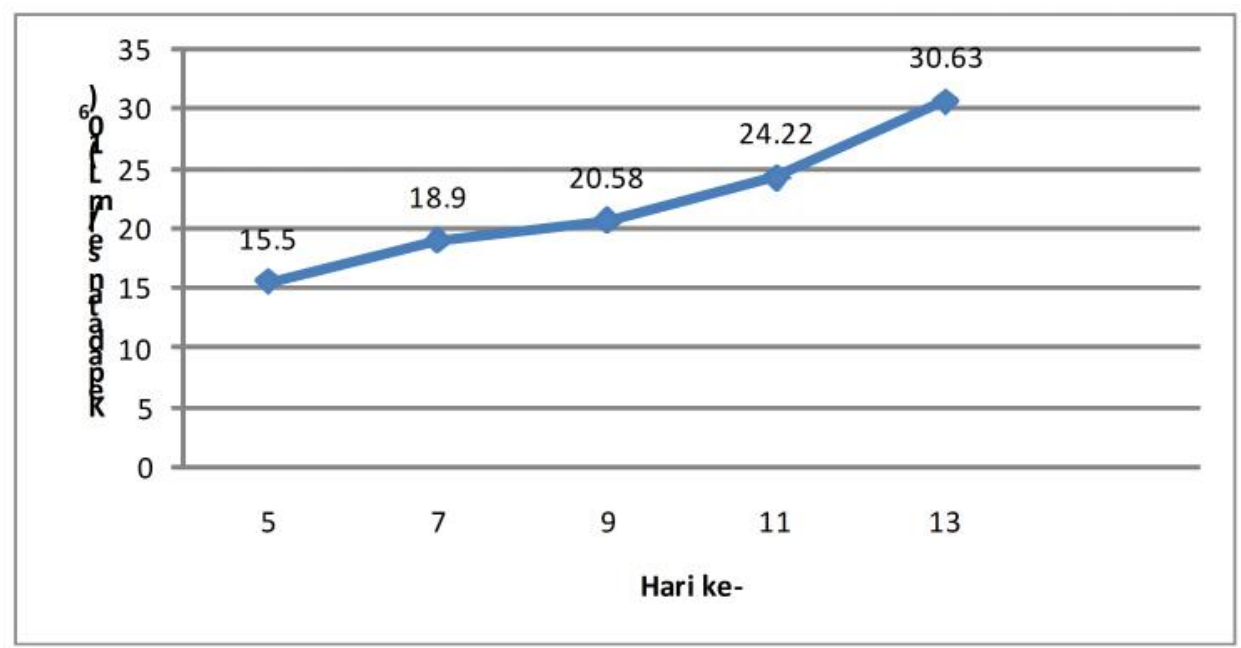

Gambar 1. Grafik Hubungan Umur Panen Terhadap Kepadatan Sel Nitzschia sp. (Sel/mL)

Dari Gambar 1 di atas dapat dilihat, bahwa Nitzschia sp. memiliki pertumbuhan yang cukup baik ditandai dengan meningkatnya populasi dari hari ke-5 sampai ke-13. Peningkatan populasi dikarenakan masih tingginya kandungan nutrien yang dimanfaatkan oleh Nitzschia sp. untuk melakukan proses pertumbuhan dan reproduksi. Menurut Rizky et al. (2013) ukuran tubuh fitoplankton mempengaruhi proses pemasukan nutrien. Jika dilihat dari morfologinya, Nitzchia sp. memiliki ukuran tubuh yang kecil sehingga proses pemasukan nutrien ke dalam jaringan sel lebih cepat terjadi dan didukung oleh luas permukaan sel yang semakin besar. Faktor lain yang menyebabkan masih tingginya kandungan nutrien sampai pada hari ke- 13 yaitu
Nitzschia sp. tergolong dalam kelompok diatom yang bersifat bentik dan tidak memiliki alat gerak sehingga nutrien yang tersedia digunakan dalam proses pertumbuhan.

Selain dilihat dari morfologi Nitzschia sp., bertambahnya populasi ditandai oleh perubahan warna media kultur. Warna media kultur pada fitoplankton merupakan warna pigmen utama yang terdapat dalam sitoplasma sel yaitu klorofil (Prihantini et al., 2007). Perubahan warna media kultur semakin pekat (gelap) sesuai dengan pertambahan umur kultivasi.

3. Hubungan Umur Panen Terhadap Kandungan Lemak

Mikroalga pada umumnya memiliki beberapa kandungan nutrisi di 
dalam tubuhnya, salah satunya yaitu lemak. Menurut Chiu-Liao et al. (1983) lemak merupakan unsur pakan yang akan disimpan sebagai cadangan energi dan pendukung pertumbuhan. Komposisi kandungan lemak dipengaruhi oleh beberapa faktor diantaranya yaitu intensitas cahaya, fase pertumbuhan, suhu, ketersediaan nutrien, dan kepadatan sel. Jika dilihat dari grafik hubungan kandungan lemak dengan umur pemanenan dapat dilihat bahwa pada umur kultur hari ke-5 sampai dengan hari ke-11 mengalami penurunan dan selanjutnya mulai hari ke-11 sampai hari ke-13 mengalami peningkatan yang drastis (Gambar 2). Penurunan kandungan lemak dikarenakan Nitzchia sp. memanfaatkan lemak sebagai sumber energi untuk memperbanyak diri. Selain itu, peningkatan kandungan lemak dipengaruhi oleh faktor suhu lingkungan media kultur. Pratiwi et al. (2009) melaporkan bahwa rendahnya suhu lingkungan dapat meningkatkan asam lemak tidak jenuh. Hal tersebut sesuai dengan pernyataan, bahwa pada hari ke-13 media kultur Nitzschia sp. memiliki suhu yang paling rendah yaitu $16,16^{\circ} \mathrm{C}$ (Tabel 2).

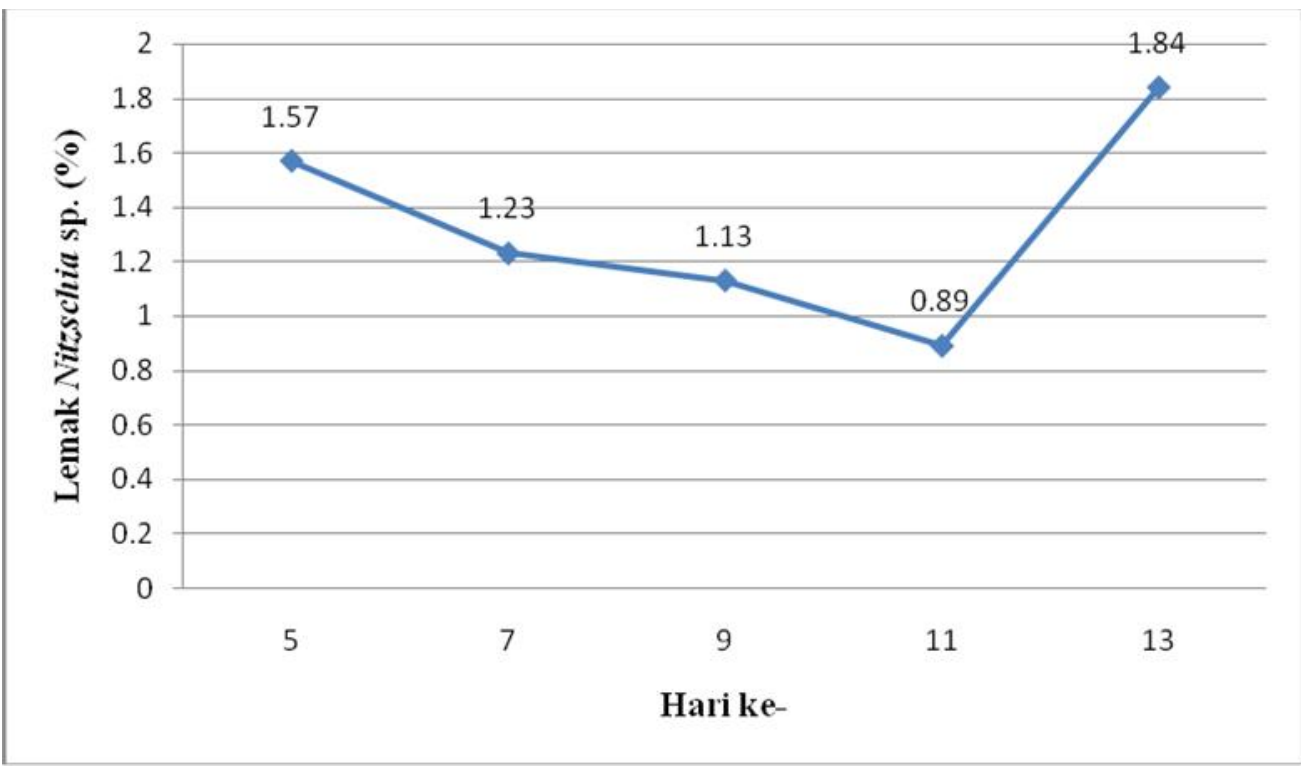

Gambar 2. Grafik Hubungan Kadar Lemak dengan Umur Panen Nitzschia sp.

\section{Hubungan Umur Panen Terhadap} Kepadatan Sel dan Kandungan Lemak

Umur panen fitoplankton pada saat kultur memiliki pengaruh yang besar terhadap kepadatan sel fitoplankton itu sendiri. Menurut BBL (2002) menyatakan bahwa umur panen yang tepat untuk fitoplankton yaitu pada umur
5-6 hari dari awal kultivasi. Pada umur tersebut fitoplankton sudah dapat beradaptasi dengan baik terhadap lingkungannya sehingga kepadatan sel semakin berlipat. Meningkatnya kepadatan sel tersebut dijadikan sebagai acuan dimulainya umur panen, mengingat fitoplankton memiliki umur yang singkat 
dalam pertumbuhannya yaitu maksimal 2 minggu dan dapat pula bertahan sampai 1 bulan namun fitoplankton berada pada fase kematian.

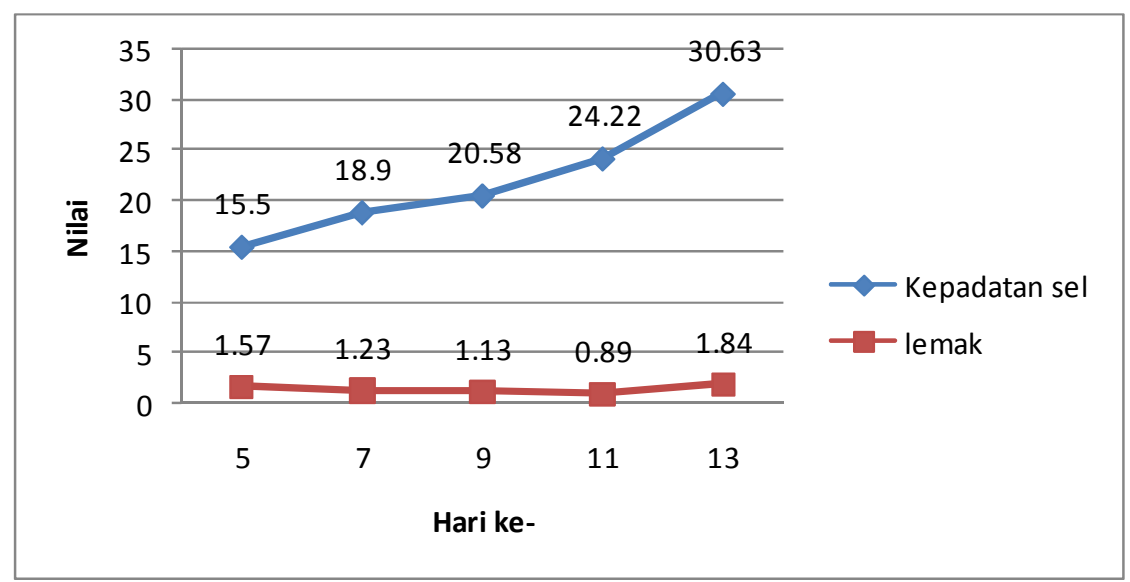

Gambar 3. Grafik Hubungan Umur Panen Terhadap Kepadatan Sel (Sel/mL) dan Kadar Lemak (\%)

Pada awal kultivasi jumlah kepadatan sel Nitzschia sp. yaitu $94 \times 10^{5}$ sel/mL. Setelah 5 hari usia kultur kepadatan selnya mencapai $15,5 \times 10^{6}$ sel/mL dengan kandungan lemak sebesar 1,57\%. Sebagai organisme akuatik, Nitzschia sp. terus tumbuh dan berkembang yang ditandai dengan bertambahnya kepadatan populasinya dari hari ke hari (Gambar 3). Pertumbuhan Nitzschia sp. dipengaruhi oleh kandungan nutrisi didalam tubuhnya dan faktor lingkungan media kultur. Tingginya kandungan nutrien menjadikan Nitzschia sp. terpenuhi akan unsur hara yang dibutuhkannya. Namun jika dilihat kandungan lemaknya, semakin hari semakin menurun dan meningkat pada akhir kultivasi (umur 13 hari). Diduga menurunnya kandungan lemak dikarenakan Nitzschia sp. memanfaatkan ketersediaan nutrien dan energi yang ada untuk pertumbuhan dan reproduksi.

\section{Faktor Lingkungan yang}

\section{Mempengaruhi Kepadatan Sel dan}

Kandungan Lemak Nitzschia sp.

Pertumbuhan Nitzschia sp. selain dipengaruhi oleh kandungan nutrisi dan kepadatan sel juga dipengaruhi oleh faktor lingkungan pada saat kultivasi sedang berlaangsung. Faktor lingkungan yang mendukung pertumbuhan Nitzschia sp. yaitu $\mathrm{pH}$, suhu ruangan, suhu media kultur, dan salinitas . Berikut ini merupakan data beberapa faktor lingkungan yang diamati pada saat kultur sebagaimana disajikan pada Tabel 2. 
Tabel 2. Faktor Lingkungan yang Mempengaruhi Media Kultur

\begin{tabular}{lcccc}
\hline No & Hari ke- & \multicolumn{3}{c}{ Faktor lingkungan } \\
\cline { 3 - 5 }$\cdot$ & & $\mathrm{pH}$ & Suhu $\left({ }^{\circ} \mathrm{C}\right)$ & Salinitas $(\mathrm{ppt})$ \\
\hline 1. & 5 & 8,30 & 18,83 & 28,67 \\
2. & 7 & 8,00 & 17,16 & 31,33 \\
3. & 9 & 8,00 & 18,67 & 30,00 \\
4. & 11 & 8,30 & 17,50 & 30,00 \\
5. & 13 & 8,30 & 16,16 & 29,30 \\
\hline
\end{tabular}

\section{a. $\mathbf{p H}$}

pH merupakan gambaran aktivitas ion hidrogen yang dijadikan salah satu faktor lingkungan yang mempengaruhi pertumbuhan fitoplankton karena $\mathrm{pH}$ dapat mengontrol tipe dan laju kecepatan reaksi beberapa nutrien di dalam media kultur. Dari hasil penelitian pengukuran $\mathrm{pH}$ didapatkan bahwa kisaran $\mathrm{pH}$ pada masing-masing media kultur yaitu 8-8,3. Menurut Balai Budidaya Laut (BBL) (2002) bahwa fitoplankton mampu tumbuh optimum pada kisaran $\mathrm{pH}$ 8-8,5. Hal tersebut menunjukkan bahwa $\mathrm{pH}$ media kultur masih aman untuk pertumbuhan Nitzschia sp.

Pada umur hari panen ke-5 sampai dengan ke-9 menunjukkan bahwa terdapat penurunan $\mathrm{pH}$ dari 8,3 menjadi 8 dan meningkat lagi pada hari panen ke-11 dan 13 menjadi 8,3 (Tabel 5). Menurunnya nilai $\mathrm{pH}$ disebabkan oleh degradasi klorofil-a sehingga fiksasi $\mathrm{CO}_{2}$ menjadi rendah dan mengakibatkan nilai $\mathrm{pH}$ menurun. Menurut Sze (1993) kenaikan nilai $\mathrm{pH}$ disebabkan adanya proses fotosintesis dimana $\mathrm{CO}_{2}$ bebas yang merupakan jenis karbon anorganik digunakan sebagai bahan baku utama pada proses fotosintesis. Selain $\mathrm{CO}_{2}$ dapat juga menggunakan $\mathrm{CO}_{3}^{2-}$ (ion karbonat) dan $\mathrm{HCO}_{3}{ }^{-}$(ion bikarbonat). Penurunan konsentrasi $\mathrm{CO}_{3}$ terlarut disebabkan oleh penyerapan $\mathrm{CO}_{3}$ bebas dan $\mathrm{HCO}_{3}{ }^{-}$ sehingga terjadinya peningkatan nilai $\mathrm{pH}$ pada media kultur.

Secara ekologis, $\mathrm{pH}$ memiliki hubungan yang sangat erat dengan lemak dan umur panen. Seperti yang telah diuraikan di atas, apabila umur panen pada Nitzschia sp. selalu bertambah tanpa adanya penambahan nutrien baik unsur makro maupun mikro dapat mengakibatkan nilai $\mathrm{pH}$ menurun dan terdapat degradasi klorofil-a sehingga fiksasi $\mathrm{CO}_{2}$ menurun. Penurunan $\mathrm{CO}_{2}$ 
yang menjadi sumber karbon utama pada saat fotosintesis tidak cukup tersedia, hal tersebut menyebabkan proses metabolisme lambat dan kelimpahan sel akan menurun. Dengan demikian kandungan lemak yang terdapat pada Nitzschia sp. akan menurun, begitupula sebaliknya.

\section{b. Suhu}

Suhu pada suatu perairan dipengaruhi oleh sirkulasi udara, musim, kedalaman badan air, dan ketinggian dari permukaan laut. Dari hasil penelitian menunjukkan bahwa kisaran suhu media kultur yaitu $16-19{ }^{\circ} \mathrm{C}$ (Tabel 5). Menurut Balai Budidaya Laut (BBL) (2002) suhu optimum untuk pertumbuhan fitoplankton yaitu $25-32{ }^{\circ} \mathrm{C}$. Namun menurut (Cotteau, 1998 ; Taw, 1990) dalam Fadilla (2010) hampir semua mikroalga toleran pada suhu antara $16-36{ }^{\circ} \mathrm{C}$. Artinya Nitzschia sp. masih mampu mentolerir suhu dibawah 25 ${ }^{\circ} \mathrm{C}$. Rendahnya suhu pada saat kultur dipengaruhi oleh suhu ruangan $\left(16^{\circ} \mathrm{C}\right)$ dan kedalaman media kultur yang kecil. Luasnya permukaan kultur mengakibatkan suhu ruangan mengalir kedalam wadah sedangkan media kultur memiliki kapasitas yang kecil sehingga mempengaruhi suhu kultur. Pada hari ke-5 dan ke-7 mengalami penurunan temperatur sedangkan pada hari ke-9 mengalami kenaikan namun pada hari ke-11 dan 15 mengalami penurunan.

Suhu yang berubah-ubah akan mempengaruhi proses fisika, kimia, dan biologi pada kehidupan fitoplankton. Menurut Sachlan (1982) kenaikan suhu akan meningkatkan laju difusi, laju fotosintesis dan merangsang aktifitas molekul. Kenaikan suhu juga mampu meningkatkan viskositas, evaporasi, reaksi kimia, volatilasi, dan menurunkan kelarutan gas dalam air sehingga pertumbuhan sel meningkat (Haslam, 1995). Namun suhu yang melebihi batas aman dapat menyebabkan denaturasi protein dan asam nukleat, kehilangan enzim, dan metabolisme sel menurun. Sedangkan penurunan suhu dapat menyebabkan laju pertumbuhan menurun dan mengakibatkan kematian.

\section{c. Salinitas}

Salinitas merupakan konsentrasi garam terlarut pada satuan air dan dijadikan sebagai salah satu faktor pembatas bagi pertumbuhan dan perkembangan fitoplankton. Dari hasil penelitian (Tabel 5) dapat dilihat bahwa salinitas berkisar antara 28,5-31,5 \%o. Menurut BBL (2002) menyatakan salinitas optimum untuk pertumbuhan fitoplankton yaitu 25-35 \%o. Dapat disimpulkan bahwa kisaran salinitas pada saat penelitian masih dapat ditolerir dan aman bagi pertumbuhan fitoplankton. Dari hasil pengamatan dapat dilihat bahwa terdapat salinitas yang berubah-ubah. Tinggi rendahnya salinitas dapat menyebabkan tekanan osmosis di dalam sel lebih rendah jika dibandingkan 
dengan diluar sel sehingga aktivitas pembelahan sel terganggu.

Dari hasil uji normalitas dapat dilihat semua data lemak valid (100\%). Berdasarkan uji normalitas dengan Kolmogorov-Smirnov Test diperoleh nilai signifikansi atau probabilitas sebesar 0,200 $>0,05$. Artinya distribusi lemak terhadap umur panen berdistribusi normal (Ho diterima). Begitu juga dengan grafik normal Q-Q Plot dimana titik-titik menyebar disekitar garis, grafik detrended normal Q-Q dimana titik-titik tersebut membentuk pola dan box plot menunjukkan bahwa data berdistribusi normal. Sedangkan, berdasarkan uji homogenitas memperlihatkan, bahwa nilai signifikansi atau probabilitas sebesar 0,028 . Artinya bahwa data kandungan lemak tidak homogen terhadap umur panen karena nilai signifikansi lebih kecil dari 0,05. Dari uji homogenitas tersebut dapat diketahui bahwa uji statistik lanjut (ANOVA) tidak dapat dilakukan, karena salah satu persyaratan tidak terpenuhi, maka uji statistik hanya sampai uji homogenitas saja.

\section{KESIMPULAN}

Pada penelitian ini dapat dilihat umur panen memiliki pengaruh yang besar terhadap kepadatan sel dan kandungan lemak Nitzschia sp.. Kepadatan sel Nitzschia sp. tertinggi terdapat pada hari ke-13 yaitu $30,63 \times 10^{6} \mathrm{sel} / \mathrm{mL}$ sedangkan kepadatan terendah pada hari ke-5 yaitu $15,5 \times 10^{6} \mathrm{sel} / \mathrm{mL}$. Kandungan lemak Nitzschia sp. tertinggi terdapat pada hari ke-13 yaitu 1,84\% dan kandungan lemak terendah pada hari ke-11 yaitu 0,89\%. Pengaruh umur panen terhadap kepadatan sel dan kandungan lemak memiliki pengaruh yang berbanding terbalik sampai hari ke-11.

\section{DAFTAR PUSTAKA}

Abida, I. W., 2010. Struktur Komunitas dan Kelimpahan Fitoplankton di Perairan Muara Sungai Porong Sidoarjo. Jurnal Kelautan, Vol 3(1): 36 - 38.

Amini, S. 2005. Konsentrasi Unsur Hara pada Media dan Pertumbuhan Chlorella vulgaris dengan Pupuk Organik Teknis dan Analisis. Jurnal Perikanan (J. Fish Sci), VIII (2): 201-206.

Balai Budidaya Laut. 2002. Budidaya Fitoplankton dan Zooplankton. Balai Budidaya Lampung. Dirjen Budidaya. Kementrian Kelautan dan Perikanan.

Chiu-Liao, I. Huei-Meei S \& Jaw-Hwa Lin. 1983. Larval Food for Penaeid Prawns. In. J. P. McVey \& J. Roobert Moore. CRC and Handbook of Mariculture. Vol. I Crustacea Aquaculture: 43-70.

Fadilla, Z. 2010. Pengaruh Konsentrasi Limbah Cair Tahu Terhadap Pertumbuhan Mikroalga Scenedesmus sp., Skripsi, $\mathrm{S}_{1}$ Program Studi Biologi Fakultas Sains Dan Teknologi: Universitas Islam Syarif Hidayatullah.

Fogg, G.E., dan B. Thake. 1987. Algal Cultures and Phytoplankton Ecology 
$3^{\text {rd }}$. London: The University of Wisconsin Press.

Haslam, S. M. 1995. Biological Indicators of Freshwater Pollution and Enviromental Management. London: Elsevier Applied Science Publisher.

Kimball, JW. 1991. Biology Jilid 1 Edisi 5. Jakarta: Erlangga.

Komarawidjaya, W. 2010. Optimalisasi Pemanfaatan Limbah Organik Sebagai Substitusi Media Kultur Mikroalga Dalam Upaya Mereduksi $\mathrm{CO}_{2}$. Laporan Penelitian. BPPT dan BTL, Serpong.

Panggabean, L. M. G., R. Sutomo, Noerdjito, dan Afdal. 2010. Mikroalga Laut Sebagai Produsen Biodiesel. Laporan Penelitian. Pusat Penelitian Oseanografi - LIPI, Jakarta.

Pratiwi, A. R., D. Syah, L. Hardjito, L. M. G. Panggabean, dan M. T. Suhartono. 2009. Fatty Acid Synthesis by Indonesian Marine Diatome, Chaetoceros gracilis. Journal of Bioscience, Vol 16 (4): 151-156.

Prihantini, N. B., W. Rachmayanti, dan W. Wardhana. 2007. Pengaruh Variasi Fotoperioditas Terhadap Pertumbuhan Chlorella dalam Medium Basal Bold. Jurnal Biota, Vol 12 (1): 32-39.

Rizky, Y. A., R. Indah, dan D. Seniwati. 2012. Penentuan Laju Pertumbuhan Sel Fitoplankton Chaetoceros calcitrans, Chlorella vulgaris, Dunaliella salina, dan Porphyridium cruentum. Artikel. Universitas Hasanuddin Makassar.

Sachlan, M. 1982. Planktonologi. Semarang: Fakultas Perikanan Undip.

Sudjana. 1996. Metoda Statistika. Bandung: Tarsito.

Sze, P. 1993. Algae. Dubuque : Brown Publisher.

Widianingsih, R. Hartati, H. Endrawati, dan M. Hilal. 2011. Kajian Kadar Total Lipid dan Kepadatan Nitzschia sp. yang Dikultur dengan Salinitas yang Berbeda. Artikel. Semarang: Universitas Diponogoro.

Wiryawan, B., M. Hkazali, dan M. Knight. 2005. Menuju Kawasan Konservasi Laut Berau Kalimantan Timur: Status sumberdaya pesisir dan proses pengembangan KKL. 